\title{
STRATEGI LAYANAN PERPUSTAKAAN PERGURUAN TINGGI PADA MASA NEW NORMAL (STUDI KASUS UPT PERPUSTAKAAN UNIVERSITAS RIAU)
}

\author{
Sastria Izprilla*), dan Hadira Latiar**) \\ Ilmu Perpustakaan, Fakultas Ilmu Budaya, Universitas Lancang Kuning, \\ Pekanbaru Indonesia \\ email : sastria49@gmail.com*) hadiralatiar6@gmailcom
}

Naskah diterima: 3 April; direvisi: 13 Juni.; disetujui: 30 Juni 2021

\begin{abstract}
Abstrak
Penelitian ini berjudul strategi layanan perpustakaan perguruan tinggi pada masa new normal (studi kasus upt perpustakaan Universitas Riau). Tujuan penelitian ini untuk mengetahui strategi layanan yang diambil oleh upt perpustakaan Universitas Riau dimasa new normal. Metode yang digunakan dalam penelitian ini adalah kualitatif dengan pendekatan deskriptif. Metode pengolahan menggunakan reduksi data, penyajian data, dan kesimpulan. Informan dalam penelitian ini yaitu kepala perpustakan, kepala bidang pelayanan, dan kepala bidang IT. Hasil penelitian ini yaitu ada beberapa strategi yang diambil oleh perpustakaan Universitas Riau yakni pengembangan digital library yang harus semakin dipercepat dan menambah aplikasi pendukung untuk menjamin kelancaran distribusi informasi kepada pemustaka.
\end{abstract}

Kata kunci : strategi, layanan perpustakaan, new normal

\begin{abstract}
This research is entitled strategy of university library services in the new normal period case study of the technical implementation unit (UPT) of the University of Riau library. The purpose of this study was to determine the service strategy taken by the technical implementing unit (UPT) of the Riau University library in the new normal era. The method used in this research is qualitative with a descriptive approach. The processing method uses data reduction, data presentation, and conclusions. The informants in this study were the head of the library, the head of the service sector, and the head of the IT department. The results of this study are that there are several strategies taken by the Riau University library, that is the development of digital libraries that must be accelerated and add supporting applications to ensure the smooth distribution of information to users.
\end{abstract}

Keyword: strategy, library service, new normal

\section{PENDAHULUAN}

Kasus Covid-19 di Indonesia pertama kali diberitahukan oleh presiden Republik Indonesia Joko Widodo pada tanggal 2 Maret 2020. Organisasi Kesehatan Dunia/World Health Organization (WHO) menyatakan penyakit covid-19 menjadi pandemi dunia pada tanggal 11 Maret 2020, dengan meningkatnya jumlah penderita dan kematian atas penyakit ini yang dimulai dari Tiongkok dan terus tumbuh secara global ke seluruh negara. Negara didunia telah menyetujui untuk menghentikan penyebaran virus Covid-19 yang lebih luas dengan melakukan pola hidup sehat, membatasi aktifitas sosial serta menjaga kebersihan diri. Dengan adanya pembatasan sosial yang dilakukan menimbulkan perubahan dari ekonomi hingga pendidikan, dikutip dari (Halem, 2020) dalam (Johan et al., 2020) yang perlu dilakukan pada bidang pendidikan dalam 
masa pandemi Covid-19 yaitu dalam aktivitas sosial, sekolah/bekerja dari rumah, dan lokakarya harus menjaga jarak agar menghindari penyebaran virus corona, membatasi aktifitas yang melibatkan banyak orang, menghindari pertemuan tatap muka dengan mengadakan teleconference, dan mengarahkan lokakarya Covid-19 secara online untuk meningkatkan kesadaran publik.

Kasus Covid-19 di Indonesia pertama kali diberitahukan oleh presiden Republik Indonesia Joko Widodo pada tanggal 2 Maret 2020. Organisasi Kesehatan Dunia/World Health Organization (WHO) menyatakan penyakit covid-19 menjadi pandemi dunia pada tanggal 11 Maret 2020, dengan meningkatnya jumlah penderita dan kematian atas penyakit ini yang dimulai dari Tiongkok dan terus tumbuh secara global ke seluruh negara. Negara didunia telah menyetujui untuk menghentikan penyebaran virus Covid-19 yang lebih luas dengan melakukan pola hidup sehat, membatasi aktifitas sosial serta menjaga kebersihan diri. Dengan adanya pembatasan sosial yang dilakukan menimbulkan perubahan dari ekonomi hingga pendidikan, dikutip dari (Halem, 2020) dalam (Johan et al., 2020) yang perlu dilakukan pada bidang pendidikan dalam masa pandemi Covid-19 yaitu dalam aktivitas sosial, sekolah/bekerja dari rumah, dan lokakarya harus menjaga jarak agar menghindari penyebaran virus corona, membatasi aktifitas yang melibatkan banyak orang, menghindari pertemuan tatap muka dengan mengadakan teleconference, dan mengarahkan lokakarya Covid-19 secara online untuk meningkatkan kesadaran publik.

Karena pandemi ini masyarakat dihimbau untuk mengikuti anjuran pemerintah seperti memakai masker, jaga jarak (social distancing) dan sering mencuci tangan dalam rangka pelaksanaan new normal. Dengan kondisi ini tentunya masyarakat dianjurkan bekerja dirumah (Work From Home). Dengan bekerja dari rumah diharapkan masyarakat dapat memberikan inovasi-inovasi kreatifitas baru untuk menambah ilmu pengetahuan. Informasi sebagai kebutuhan utama manusia dan perpustakaan sebagai penyedia informasi, saat dunia diterpa dengan adanya pandemi Covid-19 dan perpustakaan tidak luput dari imbas pandemi ini. Akibatnya penutupan pelayanan perpustakaan secara langsung menjadi penghambat akses pemustaka pada sumber informasi yang mereka butuhkan di perpustakaan.

Penutupan pelayanan perpustakaan pada masa pembatasan sosial bersekala besar (PSBB) membuat lumpuhnya penyebaran informasi kepada pemustaka. Pelayanan perpustakaan dapat diakses kembali secara online setelah diterapkannya aturan new normal atau kenormalan baru. Penerapan kenormalan baru ini dimulai pada bulan Juni tahun 2020 yang diterapkan secara berkala diseluruh provinsi di Indonesia.

Dalam menyikapi dampak dari pandemi virus corona ini, perpustakaan perguruan tinggi yang menjadi penunjang jalannya kegiatan akademik harus mengubah layanannya dari konvensional menjadi digital. Selama pandemi virus corona perpustakaan memastikan bahwa seluruh staf bekerja dari rumah kecuali sangat diperlukan. Di mana staf mulai bekerja, menjamin bahwa mereka mampu melakukannya dengan tetap memperhatikan prinsip-prinsip seputar Covid-19, menambah informasi tentang kontribusi terkomputerisasi, baik di halaman pertama situs atau dengan memasang spanduk/poster pada jendela gedung perpustakaan, mempromosikan penggunaan perpustakaan digital memakai media termasuk media yang dapat memajukan lebih banyak konten atau lisensi (IFLA, 2020). Perpustakaan harus sudah mengubah fisiknya kedalam bentuk non-fisik atau digital yang bisa diakses dimanapun dan kapanpun kepada masyarakat (Hartono, 2017). Layanan perpustakaan digital yang dibuat dengan mendadak tentunya memiliki banyak kekurangan pada konsep perpustakaan digital, maka digunakan sistem 
perpustakaan semi digital atau disebut perpustakaan hibrida.

Dari beberapa penuturan pemustaka yang sering berkunjung di UPT perpustakaan Universitas Riau bahwa karena pandemi sekarang ini pemustaka tidak dapat melakukan transaksi peminjaman dan pengembalian koleksi, hal ini menjadi penghambat kebutuhan informasi pemustaka baik untuk menyelesaikan tugas kuliah maupun sebagai bahan rujukan penelitian (Wawancara: 2020).

Berdasar dari latar belakang tersebut diatas peneliti tertarik untuk mengkaji tentang strategi yang diambil oleh UPT Perpustakaan Universitas Riau pada masa new normal. Adapun tujuan penelitian ini adalah untuk mengetahui dan menemukan bagaimana strategi layanan perpustakaan perguruan tinggi pada masa new normal di UPT perpustakaan Universitas Riau.

Dalam penelitian ini teori yang digunakan dari Suharso et.al. yaitu : a) konsep perpustakaan digital, b) komunikasi informasi, dan c) inovasi layanan pada masa covid-19. Teori yang digunakan dapat membantu dalam menjawab penelitian tentang strategi layanan pada masa new normal.

Kemudian sebagai pijakan dalam penelitian ini ada beberapa penelitian terdahulu yang relevan dengan penelitian yang penulis lakukan. Adapun penelitian tersebut adalah sebagai berikut:

Penelitian pertama oleh Suharso et.al. tahun 2020 yang berjudul "Layanan Perpustakaan Perguruan Tinggi dalam Menghadapi Pandemi Covid-19". Tujuan pada penelitian ini adalah untuk mengetahui konsep layanan digital yang bisa dilakukan dan memberikan analisis dari penerapan komunikasi informasi beberapa layanan secara online dari perpustakaan perguruan tinggi dalam memberikan layanan kepada sivitas akademika. Metode yang digunakan melalui studi literatur terhadap konsep keilmuan yang terkait dalam ilmu perpustakaan dan menganalisis beberapa publikasi dan praktek pelaksanaan oleh lembaga perpustakaan selama pandemi berlangsung. Hasil menurut penelitian ini adanya kebutuhan akan layanan perpustakaan secara online melalui penerapan konsep digital library, menjadi bentuk komunikasi informasi dari lembaga perpustakaan ke pemustakanya.

Penelitian kedua oleh Nengtyas tahun 2010 yang berjudul "Strategi Pelayanan Perpustakaan di Kantor Arsip dan Perpustakaan Daerah Kota Surakarta". Tujuan menurut penelitian ini adalah untuk menggambarkan dan mengungkapkan tentang strategi pelayanan perpustakaan di Kantor Arsip dan Perpustakaan Daerah Surakarta serta untuk mengetahui faktor pendukung dan faktor penghambat pelayanan perpustakaan. Metode penelitian yang digunakan dalam penelitian ini adalah metode penelitian deskriptif kualitatif. Hasil penelitian yang dilakukan di Kantor Arsip dan Perpustakaan Daerah Kota Surakarta dapat diketahui bahwa secara umum Kantor Arsip dan Perpustakaan Daerah Kota Surakarta telah melaksanakan strategi pelayanan perpustakaan. Strategi pelayanan perpustakaan di Kantor Arsip dan Perpustakaan Daerah Kota Surakarta meliputi: 1. Strategi Pemasaran (Relation Marketing) dilaksanakan dengan fokus terhadap pelayanan masyarakat pengguna, sosialisasi kepada masyarakat dan mendekatkan pelayanan kepada masyarakat pengguna, 2. Strategi unconditional service guarantes atau extraordinary guarantes, 3. Strategi Penanganan Keluhan, 4. Strategi Peningkatan Kinerja dilaksanakan dengan meningkatkan kualitas sumber daya manusia dan komputerisasi sistem otomasi perpustakaan.

Penelitian ketiga oleh Nurfauzi et.al. tahun 2020 yang berjudul "Peran Pustakawan Perguruan Tinggi Dalam Masa Work From Home Pandemi Covid 19". Tujuan dari penelitian ini untuk mendeskripsikan tugas dan fungsi seorang pustakawan selama work from home (WFH) dalam masa pandemi Covid-19 guna mendukung, menunjang serta 
memfasilitasi berjalan lancarnya kegiatan akademik (perkuliahan dan penelitian) di universitas serta peran yang dapat diberikan oleh pustakawan kepada masyarakat didalam masa pandemi Covid19. Metode yang digunakan dalam penulisan artikel ini ialah metode studi literatur. Teknik pengumpulan data yang digunakan adalah dokumentasi, yaitu dengan mengumpulkan sumber-sumber dokumen literatur. Hasil dan pembahasan mengenai tugas dan fungsi yang dapat dilakukan oleh pustakawan perguruan tinggi selama masa work from home diantaranya memberikan layanan online kepada dosen dan mahasiswa guna mendukung kegiatan perkuliahan, membantu memfasilitasi dosen dalam penelitian dan melakukan penelitian serta membuat karya tulis ilmiah sendiri sebagai pustakawan, mengoptimalisasikan penggunaan media sosial sekreatif, melakukan koordinasi antar sesama pustakawan, menjadi verifikator informasi guna mengurangi penyebaran hoax, serta melakukan tugas tugas kepustakawanan lainnya sesuai dengan kondisi dan dukungan fasilitas pada saat masa work from home.

\section{METODE PENELITIAN}

Metode yang digunakan dalam penelitian ini adalah deskriptif dengan pendekatan kualitatif. Menurut Arikunto (2010) penelitian deskriptif merupakan suatu penelitian yang dimaksudkan untuk mendeskripsikan informasi mengenai keadaan yang ditemui ketika penelitian dilakukan. Adapun mengenai penelitian kualitatif menurut Sugiyono (2016) penelitian kualitatif berangkat dari kasus tertentu yang terdapat dalam situasi sosial tertentu dan hasil kajiannya tidak akan diberlakukan kepopulasi, tetapi dipindahkan ke tempat lain dalam situasi sosial yang mempunyai kesamaan dengan situasi sosial dalam kasus yang dipelajari.

Informan dalam penelitian ini adalah pejabat yang ada di perpustakaan dan pemustaka sebagai pemakai layanan perpustakaan. Untuk teknik pengumpulan datanya dilakukan melalui wawancara, dengan didukung oleh hasil observasi, dokumentasi, serta studi kepustakaan. Sedangkan untuk teknik analisis data dilakukan melalui reduksi data, penyajian data, dan penarikan kesimpulan.

\section{HASIL DAN PEMBAHASAN}

Sebagaimana yang telah dipaparkan diawal tulisan, penelitian ini mengkaji tentang strategi yang diambil oleh perpustakaan dalam memberikan pelayanan pada masa new normal.

\section{a. Kebutuhan Akan Perpustakaan Digital}

Digital library saat ini menjadi pilihan terbaik untuk pelayanan di perpustakaan, karena dimasa new normal ini pemustaka tidak dapat lagi datang ke perpustakaan dan menggunakan layanan perpustakaan seperti biasanya. Adanya digital library dapat mempermudah pemustaka untuk dapat mengakses perpustakaan pada aspek pelayanan tanpa harus datang lagi ke perpustakaan.

Dengan bantuan teknologi,
perpustakaan dan pustakawan dapat
memberikan layanan melalui online.
Seperti layanan sirkulasi, dengan
perpustakaan digital maka pemustaka
dapat melakukan peminjaman dan
pengembalian buku yang berbentuk e-
book. Selain itu, perpustakaan juga dapat
memberikan fitur fitur terbaru untuk
menarik minat pemustaka untuk
menggunakan perpustakaan bukan hanya
mencari informasi tetapi juga mendapat
hiburan.

Kemudian berdasarkan hasil penelitian yang didapatkan dengan wawancara kepada informan, terungkap bahwa pada kebutuhan akan perpustakaan digital jawaban dan pendapat dari informan bahwa pelayanan secara digital menjadi sarana utama kepada pemustaka untuk mendapatkan informasi yang mereka butuhkan. Karena masa new normal ini, layanan perpustakaan secara digital menjadi inovasi terbaik yang dapat dilakukan. Pernyataan yang disampaikan Kepala UPT Perpustakaan Universitas Riau perpustakaan telah melakukan pengembangan digital library sebelum 
adanya pandemi dan memang sudah dirancang menjadi aplikasi yang dapat diakses oleh pemustaka. Beliau juga menambahkan perpustakaan menjadi pusat literasi telah menjawab kebutuhan akan digital library dengan memberikan pelayanan yang berorientasi pada layanan digital.

\section{b. Komunikasi Informasi}

Komunikasi terjadi karena interaksi antara komunikator dan komunikan yang saling bertukar informasi. Pada layanan perpustakaan tidak terlepas dari adanya komunikasi antara petugas perpustakaan dan pemustaka, dan tentunya mempengaruhi distribusi informasi dari keduanya.

Perpustakaan Univeristas Riau menggunakan email dan aplikasi Whatsapp untuk berkomunikasi dengan pemustaka demi menunjang pelayanan secara digital. dari wawancara yang telah dilakukan kepada informan terkait komunikasi informasi bahwa perpustakaan menggunakan media email dan aplikasi Whatsapp untuk berkomunikasi dengan pemustaka. Dari jawaban pemustaka, komunikasi yang dilakukan perpustakaan kepada pemustaka responnya terlihat cepat, dan tidak membuat pemustaka menunggu lama untuk mendapatkan informasi maupun layanan. Sehingga dapat dikatakan komunikasi antara perpustakaan dan pemustaka dengan berjalan lancar.

Adapun layanan peminjaman dan layanan bebas pustaka yang menggunakan Whatsapp :
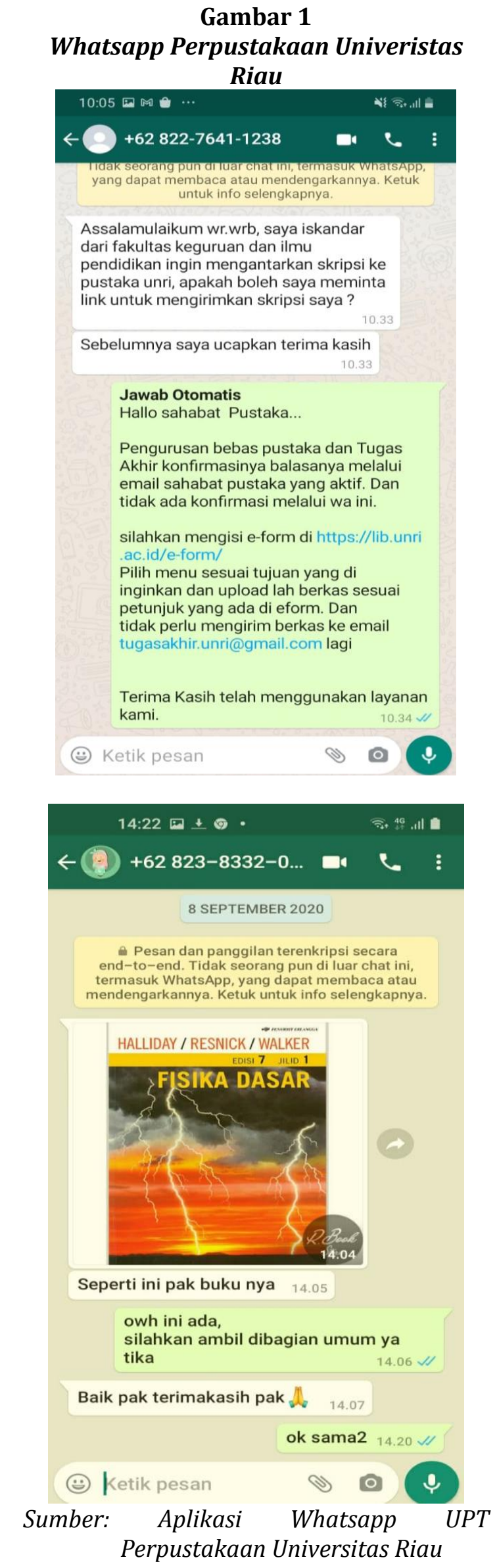
Pada kondisi new normal saat ini, inovasi ini sangat mempengaruhi kualias dari layanan perpustakaan. Respon yang cepat dari perpustakaan kepada pemustaka menjadi poin penting dalam berjalannya layanan secara digital.

\section{c. Inovasi Layanan pada Masa New Normal}

Disaat pembatasan sosial diterapkan, keberadaan perpustakaan pasti banyak dicari karena mahasiswa banyak yang membutuhkan referensi. Dengan pengembangan perpustakaan secara digital, maka pemustaka akan lebih mudah dalam mengakses informasi tanpa harus berpergian. Keuntungan lainnya pada digitalisasi ini yakni perpustakaan akan lebih terlihat keberadaannya dan dapat diakses oleh siapapun.

Perpustakaan Universitas Riau memberikan pelayanan melalui website yang berisi 14 aplikasi didalamnya untuk menunjang kebutuhan informasi maupun kebutuhan teknis kepada pemustaka.

\section{Gambar 2 \\ E-Form Perpustakaan Universitas Riau

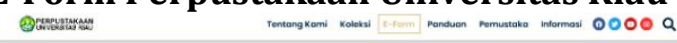

\section{E-FORM PERPUSTAKAAN}

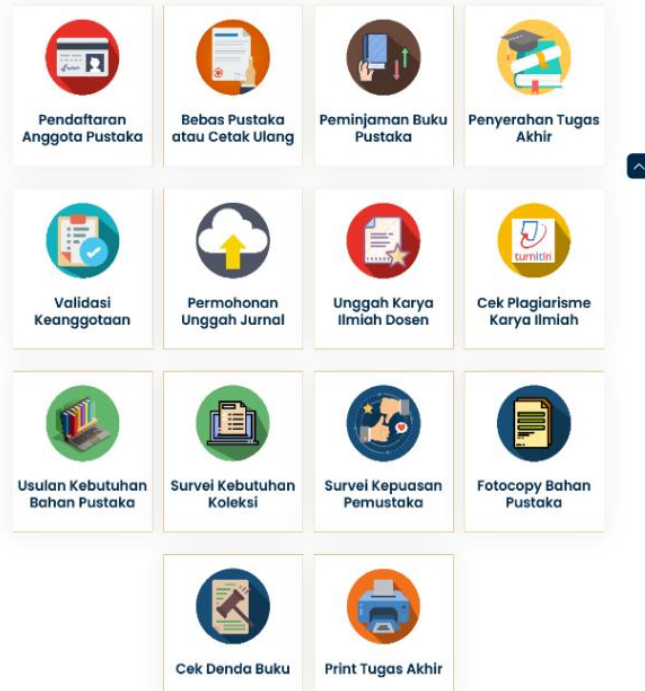

Sumber: https://lib.unri.ac.id/e-form/

Saat penulis mengobservasi eform pada website perpustakaan, terdapat 14 aplikasi didalamnya. Pelayanan yang tersedia yaitu, pendaftaran anggota perpustakaan, bebas pustaka atau cetak ulang, peminjaman buku perpustakaan, penyerahan tugas akhir, validasi keanggotaan, permohonan unggah jurnal, unggah karya ilmiah dosen, cek plagiarisme karya ilmiah, usulan kebutuhan bahan pustaka, survei kebutuhan koleksi, survei kepuasan pemustaka, fotocopy bahan pustaka, cek denda buku, print tugas akhir.

Penulis menyimpulkan jawaban dari seluruh informan tentang inovasi yang diambil oleh perpustakaan dimasa new normal ini salah satunya dengan menggunakan aplikasi eform. Jika ada permintaan masuk dari mahasiswa kemudian petugas mengecek dan mengerjakan permintaan yang masuk, lalu dikirim lagi melalui email ataupun aplikasi Whatsapp. Walau sudah mendapatkan kemudahan baik dari perpustakaan maupun pemustaka, terdapat kendala teknis yang disebabkan oleh faktor eksternal, seperti petir yang mengakitbatkan listrik dan internet mati mendadak yang berakibat terhentinya pelayanan secara daring.

\section{SIMPULAN}

Untuk kebutuhan akan digital library, pelayanan secara digital menjadi sarana utama kepada pemustaka untuk mendapatkan informasi yang mereka butuhkan. Karena masa new normal ini, layanan perpustakaan secara digital menjadi inovasi terbaik yang dapat dilakukan. Pernyataan yang disampaikan Kepala UPT Perpustakaan Universitas Riau tentang menjadi pusat literasi telah menjawab kebutuhan akan digital library dengan memberikan pelayanan yang berorientasi pada digitalisasi.

Untuk komunikasi informasi, perpustakaan menggunakan media email dan aplikasi Whatsapp untuk berkomunikasi dengan pemustaka. Dari jawaban pemustaka, komunikasi yang dilakukan perpustakaan kepada pemustaka responnya terlihat cepat, dan tidak membuat pemustaka menunggu lama untuk mendapatkan informasi maupun 
layanan. Sehingga dapat dikatakan komunikasi antara perpustakaan dan pemustaka dengan berjalan lancar.

Untuk inovasi layanan pada Masa Pandemi Covid-19, inovasi yang diambil oleh perpustakaan dimasa new normal ini salah satunya dengan menggunakan aplikasi eform. Jika ada permintaan masuk dari mahasiswa kemudian petugas mengecek dan mengerjakan permintaan yang masuk, lalu dikirim lagi melalui email ataupun aplikasi Whatsapp. Walau sudah mendapatkan kemudahan baik dari perpustakaan maupun pemustaka, terdapat kendala teknis yang disebabkan oleh faktor eksternal, seperti petir yang mengakitbatkan listrik dan internet mati mendadak yang berakibat terhentinya pelayanan secara daring.

Ketiga indikator diatas menjadi kesimpulan akhir yang berisi tentang strategi layanan yang diambil oleh perpustakaan Universitas Riau. Strategi yang diambil yaitu pengembangan digital library yang harus semakin dipercepat dan penambahan berbagai aplikasi pendukung untuk menjamin kelancaran distribusi informasi kepada pemustaka.

\section{DAFTAR PUSTAKA}

Arikunto, S. (2010). Prosedur Penelitian Suatu Pendekatan Praktik. Rineka Cipta.

Hartono, H. (2017). Strategi Pengembangan Perpustakaan Digital Dalam Membangun Aksesibilitas Informasi: Sebuah Kajian Teoritis Pada Perpustakaan Perguruan Tinggi Islam Di Indonesia. UNILIB : Jurnal Perpustakaan.

https://doi.org/10.20885/unilib.vol8. iss1.art7

IFLA. (2020). COVID-19 and the Global Library Field.

https://www.ifla.org/covid-19-andlibraries

Johan, R. C., Margana, H. H., Damayanty, D., Santika, S., Yogaswara, T. A., \& Wulandari, Y. (2020). Optimalisasi
Layanan Dalam Jejaring Perpustakaan UPI Masa Bencana Covid-19. Edulib. https://doi.org/10.17509/edulib.v10i 1.24288

Kamus Besar Bahasa Indonesia Edisi Lux (lux). (2016).

Kementrian Kesehatan. (2020). Vaksin Covid-19 Belum Ditemukan, Pemerintah Siapkan Skenario New Normal. Kementrian Kesehatan. https://www.kemkes.go.id/article/vi ew/20052900001/vaksin-covid-19belum-ditemukan-pemerintahsiapkan-skenario-new-normal.html

Peraturan Kepala Perpustakaan Nasional Republik Indonesia Nomor 13 Tahun 2017 tentang Standar Nasional Perpustakaan Perguruan Tinggi, Kepala Perpustakaan Nasional RI (2017).

Nengtyas, S. W. (2010). Strategi Pelayanan Perpustakaan Di Kantor Arsip dan Perpustakaan Daerah Kota Surakarta. Universitas Sebelas Maret.

Nurfauzi, I., Astri, N., Genepiawan, G., \& Abung, A. (2020). Peran pustakawan perguruan tinggi palam masa work from home pandemi covid 19. Peran Pustakawan Perguruan Pinggi Palam Masa Work from Home Pandemi Covid 19.

Puspa, E. (2016). Analisis Kepuasan Pemustaka Terhadap Pelayanan Perpustakaan Pusat Penelitian dan Pengembangan Perikanan Budidaya. Jurnal Pari.

Rahma, E. (2018). Akses Dan Layanan Perpustakaan: Teori dan Aplikasi. Kencana.

Rifda Herlani. (2018). Evaluasi Layanan Perpustakaan di SMA Negeri 3 Kota Tangerang Selatan. Journal of Chemical Information and Modeling.

Sugiyono. (2016). Metode Penelitian Administrasi. Alfabeta. 
Suharman. (2017). Strategi Pelayanan di Perpustakaan Dalam Meningkatkan Minat Baca Siswa di Sekolah Dasar Negeri (Sdn) 200 Bulue Kecamatan Marioriawa Kabupaten Soppeng. Universitas Islam Negeri Alauddin.
Suharso, P., Arifiyana, I. P., \& Wasdiana, M. D. (2020). Layanan Perpustakaan Perguruan Tinggi dalam Menghadapi Pandemi Covid-19. ANUVA.

Undang-Undang Perpustakaan Nomor 43 Tahun 2007. (2007). 